\title{
Change in Glycemic Control for Patients Enrolled in a Membership-Based Primary Care Program: Longitudinal Observational Study
}

Lenard I Lesser, MD, MSHS; Raj Behal, MD, MPH

One Medical, San Francisco, CA, United States

Corresponding Author:

Lenard I Lesser, MD, MSHS

One Medical

1 Embarcadero Center

Suite 1900

San Francisco, CA, 94111

United States

Phone: 18886636331

Email: LLesser@onemedical.com

\section{Abstract}

Background: Both primary care practices based on the chronic care model (CCM) and digital therapeutics have been shown to improve the care of patients with diabetes.

Objective: The aim of this observational study was to examine the change in diabetes control for patients enrolled in a membership-based primary care service that is based on the CCM.

Methods: Using a diabetes registry, we analyzed the change in glycated hemoglobin $\left(\mathrm{HbA}_{1 \mathrm{c}}\right)$ for patients with uncontrolled diabetes mellitus (initial $\mathrm{HbA}_{1 \mathrm{c}} \geq 9 \%$ ). All patients had access to a technology-enhanced primary care practice built on the CCM.

Results: The registry included 621 patients diagnosed with uncontrolled diabetes. All patients had at least two $\mathrm{HbA}_{1 \mathrm{c}}$ measurements, with the average time between the first and last measurement of 1.2 years (SD 0.4). The average starting value of $\mathrm{HbA}_{1 \mathrm{c}}$ was 10.7, which decreased to 8.7, corresponding to a reduction of $2.03(P<.001)$. Secondary analyses showed statistically significant reductions in total cholesterol, high-density lipoprotein cholesterol, low-density lipoprotein cholesterol, and triglycerides.

Conclusions: Patients with initially uncontrolled diabetes who undergo care in a technology-enhanced primary care practice based on the CCM have long-term clinically meaningful reductions in $\mathrm{HbA}_{1 \mathrm{c}}$.

(JMIR Diabetes 2021;6(2):e27453) doi: 10.2196/27453

\section{KEYWORDS}

diabetes mellitus; primary care; chronic care model; diabetes; self-management; patient; observational; digital health; decision support; decision-making; clinical information system

\section{Introduction}

Uncontrolled diabetes mellitus (DM) has serious complications, including increasing the risk for heart disease, peripheral vascular disease, and kidney disease [1]. Most patients with DM are treated in primary care [2]; yet, traditional models of primary care often do not have the adequate resources to manage this chronic disease.

The chronic care model (CCM) has been described as a way for primary care practices to control chronic diseases, including diabetes $[3,4]$. The CCM comprises 6 components that are

hypothesized to affect functional and clinical outcomes associated with disease management: (1) health system-organization of health care, (2) self-management support, (3) decision support, (4) delivery system design, (5) clinical information systems, and (6) community resources and policies.

One Medical is a membership-based (US \$199/year) primary care practice based in urban and suburban locations throughout the United States. The practice mostly serves an insured population. The practice is a Patient-Centered Medical Home, as it is built on the core attributes of primary care, along with enhanced access, a quality-improvement structure, and some 
blended payments [5]. The aim of this observational study was to assess the change in diabetes control for patients receiving care in this nationwide practice. We hypothesized that patients engaging in our primary care model, built on the principles of the CCM, would have improved glycemic control.

\section{Methods}

This was a retrospective observational analysis of primary care patients. As members of One Medical, these patients have access to all of the components of the CCM. The key features of the One Medical model and how they correspond to the CCM are shown in Table 1. All patients in our practice, including those with diabetes, have enhanced access to in-office and remote care, longer appointments, and self-management tools (eg, tracking of lab results and blood pressure on a mobile app). A patient with diabetes will have an evaluation and a care plan developed and documented in our problem-based electronic health record. Between primary care provider visits, the patient has constant virtual access to a team of clinicians, care navigators, and health coaches, all of whom are employed by One Medical. Care issues such as hypoglycemia or questions about medications can be addressed when they arise in this team-based care model.

Table 1. Chronic care model components of the One Medical model.

\begin{tabular}{ll}
\hline Chronic care model component & Feature of One Medical \\
\hline Health system & $\begin{array}{l}\text { Enhanced access with same-day primary care appointments and 24/7 access through messaging and on-demand } \\
\text { video chat }\end{array}$ \\
Self-management & $\begin{array}{l}\text { Mobile app, which provides care reminders and allows self-tracking of diabetes lab results and blood pressure } \\
\text { Decision support }\end{array}$ \\
Delivery system design & $\begin{array}{l}\text { Care navigators and virtual care providers who can manage patient care between visits with their primary care } \\
\text { providers }\end{array}$ \\
Clinical information systems & Population health and quality improvement infrastructure that allows tracking of process metrics and outcomes
\end{tabular}

We used an existing quality-improvement registry of One Medical members with prediabetes and diabetes $(\mathrm{N}=7805)$ who had at least two glycated hemoglobin $\left(\mathrm{HbA}_{1 \mathrm{c}}\right)$ lab measurements over a follow-up period of 180 days or longer as the source for our analysis. The registry is derived from our health system's proprietary electronic health record, including all types of DM, with data collected from 2017 to 2020 . The registry's primary use is to improve the quality of care for patients with diabetes. From this registry, we selected a sample of patients whose first $\mathrm{HbA}_{1 \mathrm{c}}$ result in the practice showed their condition as uncontrolled $\left(\mathrm{HbA}_{1 \mathrm{c}} \geq 9 \%\right)$. We performed a retrospective analysis of changes in lab-measured $\mathrm{HbA}_{1 \mathrm{c}}$ for this sample of patients with uncontrolled diabetes.

We report the basic demographics, BMI, as well as the Charleston Comorbidity Index (CCI) of our patients. The CCI is a chronic disease scoring system that is correlated with 10 -year risk of mortality [6]. The CCI generally gives $1-6$ points for each chronic disease a patient has and 1 point for every decade over age 50 . The predicted 10 -year survival is $96 \%$ for patients with a score of $1,90 \%$ for those with a score of $2,77 \%$ for those with a score of 3 , and so on.
We analyzed the change in $\mathrm{HbA}_{1 \mathrm{c}}$ between the initial and last available value using a paired $t$ test. In secondary analyses, we also evaluated changes in total cholesterol, low-density lipoprotein (LDL) cholesterol, high-density lipoprotein (HDL) cholesterol, and triglycerides. Very few patients had missing data, and therefore we chose to not remove any patients due to missing data. We used STATA Version 14 for all analyses.

\section{Results}

The analysis included a dataset for 621 patients $(8 \%$ of the registry of 7805 patients) who met our inclusion criteria as their diabetes was uncontrolled upon presentation. The average time between lab values was 1.2 years (SD 0.4). The characteristics of the patients at the time of data extraction from the registry are shown in Table 2. Patients had a median CCI of 2, indicating that the majority of patients had an additional chronic disease or were over the age of 50 .

Table 3 shows the change in lab values. There was an overall decrease in the mean baseline and follow-up $\mathrm{HbA}_{1 \mathrm{c}}$, total cholesterol, LDL cholesterol, and triglycerides, with an average increase in HDL cholesterol. 
Table 2. Characteristics of patients ( $\mathrm{N}=621)$.

\begin{tabular}{ll}
\hline Characteristic & \multicolumn{1}{l}{ Value } \\
\hline Age (years), mean (SD) & $51.2(12.0)$ \\
Female, $\mathrm{n}(\%)$ & $189(30.4)$ \\
$\mathrm{BMI}\left(\mathrm{kg} / \mathrm{m}^{2}\right)$, median $(\mathrm{IQR})^{\mathrm{a}}$ & $31.5(27.6-36.2)$ \\
$\mathrm{CCI}^{\mathrm{b}}$ score, median (IQR) & $2(2-4)$ \\
Major depressive disorder, $\mathrm{n}(\%)$ & $126(20.3)$ \\
Generalized anxiety disorder, $\mathrm{n}(\%)$ & $26(4.2)$ \\
\hline
\end{tabular}

${ }^{\mathrm{a}} \mathrm{BMI}$ data were missing for 76 (12\%) patients.

${ }^{\mathrm{b}} \mathrm{CCI}$ : Charleston Comorbidity Index.

Table 3. Changes in glycated hemoglobin $\left(\mathrm{HbA}_{1 \mathrm{c}}\right)$ and cholesterol.

\begin{tabular}{|c|c|c|c|c|c|}
\hline Variables & Patients, $\mathrm{N}$ & First value, mean (SD) & Latest value, mean (SD) & Mean difference $(95 \% \mathrm{CI})$ & $P$ value $^{\mathrm{a}}$ \\
\hline $\mathrm{HbA}_{1 \mathrm{c}}(\%)$ & 621 & $10.7(1.44)$ & $8.7(2.16)$ & $-2.03(-1.85$ to -2.20$)$ & $<.001$ \\
\hline Total cholesterol (mg/dl) & 599 & $192.9(63.2)$ & $172.7(60.8)$ & $-20.2(-16.3$ to -24.1$)$ & $<.001$ \\
\hline $\mathrm{LDL}^{\mathrm{b}}$ cholesterol (mg/dl) & 542 & $103.4(40.1)$ & $90.7(38.9)$ & $-12.6(-9.86$ to -15.4$)$ & $<.001$ \\
\hline $\mathrm{HDL}^{\mathrm{c}}$ cholesterol $(\mathrm{mg} / \mathrm{dl})$ & 596 & $43.3(13.7)$ & $44.5(13.4)$ & $+1.2(0.60$ to 1.8$)$ & $<.001$ \\
\hline Triglycerides, mg/dl & 597 & $263.1(443.5)$ & $206.0(173.6)$ & $-57.0(-37.2$ to -76.8$)$ & $<.001$ \\
\hline
\end{tabular}

${ }^{\mathrm{a}}$ Based on a two-sided $t$ test.

${ }^{b}$ LDL: low-density lipoprotein.

${ }^{\mathrm{c}} \mathrm{HDL}$ : high-density lipoprotein.

\section{Discussion}

\section{Principal Results}

This analysis shows that a technology-enhanced primary care practice based on the principles of the CCM can effectively control diabetes. As hypothesized, patients who had uncontrolled diabetes on initial presentation showed a marked reduction in $\mathrm{HbA}_{1 \mathrm{c}}$ after engaging in technology-enhanced primary care that utilizes the CCM.

\section{Comparison With Prior Work}

Other technology-enabled diabetes interventions outside of primary care settings have also shown promise. A program focusing on diets and virtual coaching showed a $1.3 \%$ reduction in $\mathrm{HbA}_{1 \mathrm{c}}$ over 1 year [7]. A similar program delivered via a mobile app showed a reduction of $1.1 \%$ over 12 weeks for patients who had an initial $\mathrm{HbA}_{1 \mathrm{c}}>7 \%$ [8]. A remote monitoring intervention for diabetes with an average starting $\mathrm{HbA}_{1 \mathrm{c}}$ of $8.5 \%$ showed a $1 \%$ decrease in $\mathrm{HbA}_{1 \mathrm{c}}$ over 12 weeks [9]. The same program showed a nonsignificant decrease of $0.66 \% \mathrm{HbA}_{1 \mathrm{c}}$ at 1 year [10]. However, patients on insulin, who started with a higher $\mathrm{HbA}_{1 \mathrm{c}}$, had a statistically significant $0.9 \%$ decrease in $\mathrm{HbA}_{1 \mathrm{c}}$.

In comparison to the above studies, our population showed a reduction of $2 \%$ in $\mathrm{HbA}_{1 \mathrm{c}}$. This improvement is clinically meaningful as each $1 \%$ reduction in mean $\mathrm{HbA}_{1 \mathrm{c}}$ is associated with relative risk reductions of $21 \%$ for deaths related to diabetes, $14 \%$ for myocardial infarction, and $37 \%$ for microvascular complications [11]. The likely reason we were able to show larger reductions was because our program combined two methods that have been shown to improve diabetes care: technology-delivered care and care based on the CCM. The above-cited studies used technology and remote care, but were not integrated in a primary care practice. Incorporating a diabetes management program with primary care practices enables accessing additional patient touch points and engagement.

A systematic review has shown that the CCM is being used across the United States to treat diabetes in primary care, with some large interventions showing improvement in diabetes control $[4,12]$. However, one study in the Netherlands using the CCM found reductions in cardiovascular risk factors, but not improvement in $\mathrm{HbA}_{1 \mathrm{c}}$ [13]. One study on chronic care clinics showed that the reduction of $\mathrm{HbA}_{1 \mathrm{c}}$ was dependent on the number of interactions with the patient [14]. Other research has shown that simply displaying reminders to providers in the electronic health record can improve process metrics, but not glycemic control [15,16]. Yet, increasing provider continuity - the basis of good primary care-does seem to improve disease control [17]. Further, adding specialty care to primary care does not seem to improve the control of diabetes [18]. Ease of access and the availability of a smartphone app for patient-provider communication may have contributed to effective diabetes control in our CCM-based care model. Our results provide further evidence that implementing the CCM for diabetes care in primary care can improve diabetes control. 


\section{Limitations}

This study's design is the main limitation, as it was observational. It is possible that these patients would improve with any primary care model, even one that does not include the components of the CCM. Since we selected patients who had uncontrolled diabetes with a high baseline $\mathrm{HbA}_{1 \mathrm{c}}$, regression to the mean may explain some of the reductions in $\mathrm{HbA}_{1 \mathrm{c}}$ we observed. However, if the underlying theory of the CCM is correct, then any practice that incorporates the key features of the CCM, such as ours, should improve care.

The anticipated reduction in future cardiovascular risk may be further enhanced by lowering of LDL cholesterol as noted in this analysis. Although we did not analyze medications in this study, it is likely that many of these patients were placed on a statin. The likely reason for continued elevations in triglycerides is that our practice's standard procedure is to test nonfasting cholesterol levels. Thus, the levels would be higher than observed in previous studies that found a correlation between triglycerides and elevated cardiovascular risk. Even if these levels confer an elevated cardiovascular risk, triglycerides have a very small independent effect on this risk [19].

Findings such as the higher variance in follow-up $\mathrm{HbA}_{1 \mathrm{c}}$ than in the initial measurement could not be further assessed due to the limited number of variables included in this dataset. This can be common in studies where some individuals respond to treatment and others do not. Future research should assess potential contributors to variance in similar cohorts.

\section{Conclusions}

We demonstrated that patients with uncontrolled diabetes who receive ongoing care in a technology-based primary care model can achieve marked improvements in glycemic control. With sustained improvements, these patients will have a reduced risk for the micro- and macrovascular complications of diabetes attributed to glycemic control. This study provides further evidence that primary care practices that adopt the CCM as a model of care can improve diabetes care.

\section{Acknowledgments}

The authors would like to thank John Schrom for constructing the registry and providing feedback on the analysis. The study was funded by internal funds from One Medical.

\section{Authors' Contributions}

LIL and RB both contributed to study design, data analysis, and manuscript writing.

\section{Conflicts of Interest}

Both authors are employees and hold equity in One Medical, the sponsor of the study.

\section{References}

1. Centers for Disease Control and Prevention. Diabetes Report Card 2019. Atlanta, GA: US Department of Health and Human Services URL: https://www.cdc.gov/diabetes/pdfs/library/Diabetes-Report-Card-2019-508.pdf [accessed 2021-05-26]

2. Grumbach K, Bodenheimer T. A primary care home for Americans: putting the house in order. JAMA 2002 Aug 21;288(7):889-893. [doi: 10.1001/jama.288.7.889] [Medline: $\underline{12186609]}$

3. Bodenheimer T, Wagner EH, Grumbach K. Improving primary care for patients with chronic illness. JAMA 2002 Oct 09;288(14):1775-1779. [doi: 10.1001/jama.288.14.1775] [Medline: 12365965]

4. Stellefson M, Dipnarine K, Stopka C. The chronic care model and diabetes management in US primary care settings: a systematic review. Prev Chronic Dis 2013;10:E26 [FREE Full text] [doi: 10.5888/pcd10.120180] [Medline: 23428085]

5. Stange KC, Nutting PA, Miller WL, Jaén CR, Crabtree BF, Flocke SA, et al. Defining and measuring the patient-centered medical home. J Gen Intern Med 2010 Jul 14;25(6):601-612 [FREE Full text] [doi: 10.1007/s11606-010-1291-3] [Medline: 20467909]

6. Charlson ME, Pompei P, Ales KL, MacKenzie C. A new method of classifying prognostic comorbidity in longitudinal studies: development and validation. J Chronic Dis 1987;40(5):373-383. [doi: 10.1016/0021-9681(87)90171-8] [Medline: 3558716]

7. Hallberg SJ, McKenzie AL, Williams PT, Bhanpuri NH, Peters AL, Campbell WW, et al. Effectiveness and safety of a novel care model for the management of type 2 diabetes at 1 year: an open-label, non-randomized, controlled study. Diabetes Ther 2018 May;9(2):583-612 [FREE Full text] [doi: 10.1007/s13300-018-0373-9] [Medline: 29417495]

8. Berman MA, Guthrie NL, Edwards KL, Appelbaum KJ, Njike VY, Eisenberg DM, et al. Change in glycemic control with use of a digital therapeutic in adults with type 2 diabetes: cohort study. JMIR Diabetes 2018 Mar 14;3(1):e4 [FREE Full text] [doi: 10.2196/diabetes.9591] [Medline: 30291074]

9. Bollyky JB, Bravata D, Yang J, Williamson M, Schneider J. Remote lifestyle coaching plus a connected glucose meter with certified diabetes educator support improves glucose and weight loss for people with type 2 diabetes. J Diabetes Res 2018;2018:3961730. [doi: 10.1155/2018/3961730] [Medline: 29888288]

10. Bollyky JB, Melton ST, Xu T, Painter SL, Knox B. The effect of a cellular-enabled glucose meter on glucose control for patients with diabetes: prospective pre-post study. JMIR Diabetes 2019 Oct 07;4(4):e14799 [FREE Full text] [doi: 10.2196/14799] [Medline: 31593545] 
11. Stratton IM, Adler AI, Neil HA, Matthews DR, Manley SE, Cull CA, et al. Association of glycaemia with macrovascular and microvascular complications of type 2 diabetes (UKPDS 35): prospective observational study. BMJ 2000 Aug 12;321(7258):405-412 [FREE Full text] [doi: 10.1136/bmj.321.7258.405] [Medline: 10938048]

12. Peterson KA, Radosevich DM, O'Connor PJ, Nyman JA, Prineas RJ, Smith SA, et al. Improving diabetes care in practice: findings from the TRANSLATE trial. Diabetes Care 2008 Dec 22;31(12):2238-2243 [FREE Full text] [doi:

10.2337/dc08-2034] [Medline: 18809622]

13. Cleveringa FG, Gorter KJ, van den Donk M, Rutten GE. Combined task delegation, computerized decision support, and feedback improve cardiovascular risk for type 2 diabetic patients: a cluster randomized trial in primary care. Diabetes Care 2008 Dec 16;31(12):2273-2275 [FREE Full text] [doi: 10.2337/dc08-0312] [Medline: 18796619$]$

14. Wagner EH, Grothaus LC, Sandhu N, Galvin MS, McGregor M, Artz K, et al. Chronic care clinics for diabetes in primary care: a system-wide randomized trial. Diabetes Care 2001 May 01;24(4):695-700. [doi: 10.2337/diacare.24.4.695] [Medline: $\underline{11315833]}$

15. Maclean CD, Gagnon M, Callas P, Littenberg B. The Vermont diabetes information system: a cluster randomized trial of a population based decision support system. J Gen Intern Med 2009 Dec 28;24(12):1303-1310 [FREE Full text] [doi: 10.1007/s11606-009-1147-x] [Medline: $\underline{19862578]}$

16. Renders C, Valk G, Griffin S, Wagner E, Eijk JV, Assendelft W. Interventions to improve the management of diabetes mellitus in primary care, outpatient and community settings. Cochrane Database Syst Rev 2001(1):CD001481 [FREE Full text] [doi: 10.1002/14651858.CD001481] [Medline: 11279717]

17. Lustman A, Comaneshter D, Vinker S. Interpersonal continuity of care and type two diabetes. Prim Care Diabetes 2016 Jun;10(3):165-170. [doi: 10.1016/j.pcd.2015.10.001] [Medline: 26530317]

18. Smith SA, Shah ND, Bryant SC, Christianson TJ, Bjornsen SS, Giesler PD, Evidens Research Group. Chronic care model and shared care in diabetes: randomized trial of an electronic decision support system. Mayo Clin Proc 2008 Jul;83(7):747-757. [doi: 10.4065/83.7.747] [Medline: 18613991]

19. Ye X, Kong W, Zafar MI, Chen L. Serum triglycerides as a risk factor for cardiovascular diseases in type 2 diabetes mellitus: a systematic review and meta-analysis of prospective studies. Cardiovasc Diabetol 2019 Apr 15;18(1):48 [FREE Full text] [doi: 10.1186/s12933-019-0851-z] [Medline: $\underline{\text { 30987625] }}$

\section{Abbreviations \\ CCI: Charleston Comorbidity Index \\ CCM: chronic care model \\ DM: diabetes mellitus \\ $\mathbf{H b A}_{1 \mathbf{c}}$ : glycated hemoglobin A1c \\ HDL: high-density lipoprotein \\ LDL: low-density lipoprotein}

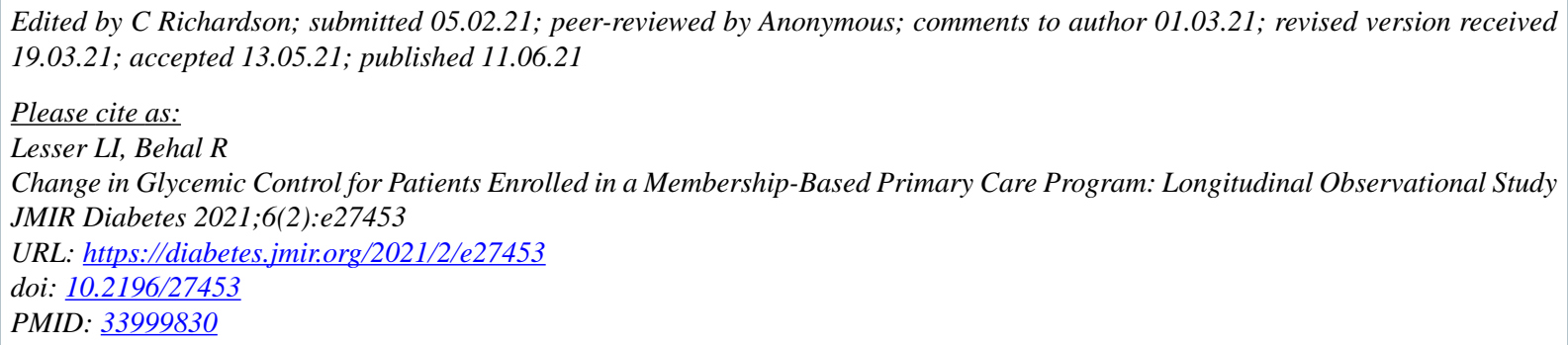

CLenard I Lesser, Raj Behal. Originally published in JMIR Diabetes (https://diabetes.jmir.org), 11.06.2021. This is an open-access article distributed under the terms of the Creative Commons Attribution License (https://creativecommons.org/licenses/by/4.0/), which permits unrestricted use, distribution, and reproduction in any medium, provided the original work, first published in JMIR Diabetes, is properly cited. The complete bibliographic information, a link to the original publication on https://diabetes.jmir.org/, as well as this copyright and license information must be included. 